\title{
The Importance of Early Attachment Relationships in Current Psychoanalysis
}

\author{
Eun Jung Li and Jaehak Yu \\ Department of Psychiatry, Konkuk University Medical Center, Seoul, Korea
}

\section{현대 정신분석에서의 초기 애착관계의 중요성}

\author{
이 은 정 유 재 학 \\ 건국대학교병원 정신건강의학과
}

\begin{abstract}
Both psychoanalysis and psychoanalytic psychotherapy are psychiatric modalities for investigating the human mind, especially the unconscious mind. The therapist helps his patients by understanding them through conversation and interpreting their unconscious mind based on their free associations. Therefore, both psychoanalysis and psychoanalytic psychotherapy have emphasized the interpretation of therapist and the insight of patient. However, the patient-therapist interaction is an important factor of therapy in addition to the therapists' interpretation. We defined the meaning and concept of mental development and reviewed the Freud's epigenesist theory, the Klein's position theory and the development theory on post-adolescence. We summarized the ontological motives of mental development and the correlation between the development theory and the psychoanalysis theory. We indicated that the patient-therapist relationship is especially important to children and lower-level personality disorder patients. Therefore, we focused the similarities between the child-mother and the patient-therapist relationships and the development of interaction. We concluded that mental development is the process that brings about new functions and transformation of the individual and continues through his entire life. We suggested that mutual interactions concurrently lead to mental development of individual and the interaction itself. From this point of view, we discuss why the patient's first experience of containing achieved through the patient-therapist relationship serves as a therapeutic factor of psychoanalysis. Finally, we suggest that therapist's rephrasing and summary of their interaction to the patient during the psychoanalysis is one of the key factors of psychoanalysis.

Psychoanalysis 2016;27(2):54-61
\end{abstract}

KEY WORDS: Mental development · Psychoanalysis · The patient-therapist relationship.

Received: March 14, 2016 Revised: April 5, 2016 Accepted: April 6, 2016

Address for correspondence: Jaehak Yu, MD

Department of Psychiatry, Konkuk University Medical Center, 120-1 Neungdong-ro, Gwangjin-gu, Seoul 05030, Korea

Tel: +82-2-2030-7566, Fax: +82-2-2030-7390, E-mail: drjaehakyu@yahoo.co.kr

\section{서 론}

인간은 출생부터 성인기까지 신체적 발달을 계속하는 것 에 대비되어 정신적 발달을 출생부터 사망까지 계속한다. 과 거에는 사춘기 이후에 정신적인 자아의 발달이 이루어지지 않는다는 이론이 지배적이었으나 최근에는 발달이 내부의 생물학적인 시간표에 따라 진행이 될 뿐 아니라, 사춘기 이후 성인기는 물론 노년기까지 정신적 발달이 이루어 지고 있다

This is an Open Access article distributed under the terms of the Creative Commons Attribution Non-Commercial License (http://creativecommons.org/licenses/by-nc/3.0) which permits unrestricted non-commercial use, distribution, and reproduction in any medium, provided the original work is properly cited.
고 보고 있다. 이로써 발달은 정신의 평형상태를 깨는 자극이 존재하는 한 계속되며, 이러한 자극들에 적응하며 개개인이 변화하는 것을 의미하는 것으로 발달의 개념을 확장할 수 있다.

아동의 발달에서 성장(growth) 또는 발육은 생물학적인 의 미로서의 변화를 강조하고 있다. 근본적으로 유전자의 활동 에 의해 결정되는 신체적 발달뿐 아니라, 이미 예정되어 있 던 부분들이 출현하면서 변화되는 과정을 성숙(maturation) 이라고 한다. 그러나 인간의 정신적 발달은 단순히 성장과 성 숙에 국한되는 것이 아니라, 이전 단계에서는 전혀 수행할 것 이라고 예상하지 못한 일을 할 수 있는 능력을 획득하는 것을 포함하며, 예정되어 있는 한계를 뛰어넘어서 이전과는 다른 
새로운 단계에서의 변화(transformation)를 보이는 것을 의미 한다(Abrams 1983).

이러한 인간의 발달이 개인의 유전적 요인과 부모의 양육, 사회문화적 - 환경적 요인에 의해서 영향을 받듯이 정신적 발 달은 개인의 발달뿐만 아니라 개인과 타인에 의한 상호작용 같은 정신적 환경 요인에 의해서도 영향을 받게 된다. 정신적 환경에 의한 상호작용 중 가장 중요한 것은 초기 유아기의 모 성과의 상호작용에 의한 모자관계(child-mother relationship)임은 주지하는 바이다. 또한 모자관계가 상호작용의 영 향으로 유아와 모성 개인의 발달을 이끌기도 하지만, 모자관 계 자체도 시간이 감에 따라 발달을 거듭한다고 하겠다.

개인의 발달에 있어서 모자관계와 같은 상호작용이 중요 하다는 이론과 이러한 상호작용 자체도 시간이 가며 발달한 다는 이론은 정신분석 혹은 분석적 정신치료의 과정에 그대 로 적용할 수 있다. 그러므로 환자-치료자 관계가 정신분석 혹은 분석적 정신치료의 과정에 어떠한 영향을 미치는지 치 료 과정을 모자관계와 연결하여 연구하는 것은 최근의 정신 분석 혹은 분석적 정신치료의 화두가 되었다. 또한 치료자의 해석을 통한 환자의 통찰과 더불어, 정신분석 혹은 분석적 정신치료의 치료인자로서 환자-치료자 관계의 발달이 중요 한 역할을 한다는 사실이 받아들여지면서 모자관계를 다시 재 조명하게 만들었다. 다시 말하면, 1990 년대까지는 환자의 내 부에서 일어난다고 할 수 있는 전이신경증(transference neurosis)의 발달과 이것의 해결이 정신분석 과정의 가장 중요한 요소라는 생각으로부터, 1990년대 이후부터는 환자와 치료자 사이에 이루어지는 상호작용의 발달이 정신분석의 치료요소 로서 가장 중요하다는 생각으로의 변화를 의미한다. 이것은 최근의 실제 정신분석 임상현장에서 신경증 환자들보다 통 합적 자기 인식의 어려움 혹은 심한 대인관계의 갈등을 보이 는 좀 더 심한 정신병리를 가진 낮은 수준의 인격장애 환자들 을 치료하게 되는 현상과 맥락을 같이 한다. Diagnostic and Statistical Manual of Mental Disorders(DSM)-5 작업팀이 초기에 제안한 인격장애 개정안의 가장 혁신적인 변화 역시 자기와 타인에 대한 왜곡된 사고로 인한 대인관계 기능의 이 상이었다. 비록 최종적으로 공식 발표된 DSM-5 전체에서 인격장애 부분은 DSM-fourth edition-text revision에 그대로 머물긴 했으나, 이는 현대 정신의학에서 정신발달학적 관점 에서 상호적인 대인관계의 중요성을 반증하는 것이라고 하 겠다(Choi와 Ha 2013).

이렇듯이 현대 정신분석에서 발달의 의미가 중요한데 비 해서, 새로운 발달이론이 미흡하고 발달이론들이 각기 발전 하면서 통합적 이론으로써 이해하는 데 어려움이 있다. 그러 므로 저자들은 통합적인 측면에서 기존 정신분석의 발달이론
들의 핵심을 관통하는 요인이 무엇인지 확인하고 밝히는 것 이 현대 정신분석과 정신치료에서 매우 중요한 일이라고 생 각하였다. 따라서 저자들은 정신분석의 치료요인으로서 환 자-치료자 상호관계가 미치는 영향이 무엇보다도 중요하다 는 가설하에, 기존 정신분석적 발달이론을 비판적 관점에서 고찰한 후 발달이론에 대해 통합적인 관점의 이론을 위한 제안을 세워 보려고 한다.

\section{본 론}

\section{발달의 의미와 개념}

인간의 발달은 생물학적인 의미의 성장(growth), 성숙(maturation)과 변형(transformation)으로 구분할 수 있다. 생물 학적인 발달의 의미는 성장(growth)으로, 출생부터 사춘기까 지 성장하면서 일어나는 발육의 개념에 근접하다. 성숙(maturation)은 인간이 본래 유전적으로 지니고 있던 부분이 시 간이 지남에 따라 자연스럽게 출현하는 개념으로, 그 완성 단 계에서 생물학적으로 본래 정해진 한계가 있으므로, 인간의 발달을 성숙의 관점으로만 설명할 수는 없다. 반면, 변형(transformation)은 그러한 한계를 넘어, 이전 단계에서는 불가 능하였던 일을 수행할 수 있는 새로운 능력을 획득하는 것을 말한다. 즉 과거에는 발달이 이전 단계에서부터 연속적(continuous)으로 일어난다고 보았다면(Figure 1A), 변형을 한다 는 것은 발달이 비연속적(discontinuous)으로 일어난다는 것 이다(Figure 1B). 비연속적인 발달이라 함은, 2007년 개봉한 영화 '트랜스포머'에서 평범한 자동차 '범블비'가 변신하여 로봇 '범블비'가 되면서 새로운 기능을 획득하는 것을 예로 들 수 있다. 즉 자동차가 이전에는 누구도 자동차의 기능으 로서는 상상하기 힘들었던 로봇의 기능을 새로 획득함으로 써 다른 단계로 도약(jumping)하는 것을 생각할 수 있다.

인간의 성장과 발육이 유전적 형질의 영향뿐 아니라 개인 의 환경의 영향을 받듯이, 정신적인 발달도 역시 그러한 주변 성장 환경에 의한 영향을 받게 된다. 다만, 생물학적인 발육 과는 달리 정신적인 발달은 유전적인 형질에 의한 한계점이 존재한다고 보기 어렵다. 이것은 개개인의 발달이 태어날 때 부터 정해진다는 결정론적인 관점과는 대비되는 것이며, 정 신적 발달이 성숙(maturation)의 개념보다는 변형(transformation)의 개념에 더 가깝다는 것을 의미한다.

정신분석 과정에서의 발달의 의미는 그동안의 관습적인 의미와 특별히 기술적인 의미로서 혼용하여 쓰여 왔으며, 많 은 학자들과 임상가들 사이에 논쟁이 되어 왔다. 통상적으로 사용되는 '발달’은, 첫째, 분석적 치료 과정 중에 발생하는 모 든 일(happening, event)을 지칭하므로, 분석 과정 중에서 환 
자에게 일어나는 모든 일들을 포함한다. 둘째, 그보다 제한 적인 범위에서의 개념은 분석치료 과정이 진행될수록 전이 현상이 강해지면서 발생하는 결과(outcome)이다. 셋째, 결과 중에서도 특히 긍정적인 결과, 즉 분석치료가 진행되면서 환 자가 표현하는 억제(repression)가 완화되고, 인간관계가 넓 어지면서, 환자 주변에서 일어나는 일들에 대한 다양한 의미 와 감정을 수용하게 되는 좋은 결과(enhancement)들을 발 달이라고 하였다. 그러나 발달은 정신분석학에서는 매우 복 잡하고 특수화된 의미를 내포하고 있으며, 소아의 연속적인 성장뿐 아니라, 성인이 정신분석적 환경에서 회상을 통하여 자신의 기억을 재구성하면서 일어나는 정신적 성장을 뜻한 다(Abrams 1983).

\section{발달이론의 확장}

Freud는 발달의 개념을 후성설(epigenesis)에 착안하여 단 계적인 발달이론을 제기하였다. Freud는 그의 경력 초기부 터 다윈의 진화론과 신경학적인 이론들, 발생학으로부터 영 향을 받아 왔으며, 일찍이부터 인간의 정신발달에 대해 관심 을 가졌다. Freud는 인간의 정신의 발달도 생물의 개체발생 과 같이 선행하는 시기의 성공 후에 다음 시기가 온다는 이론 을 세웠다. 즉 인간 정신의 발달은 누적되며, 인간은 선행하 는 발달 단계의 성공이 이루어진 후 다음 단계의 발달과제를 수행하게 된다고 생각하였다. 이로써 추후에 일어나는 발달 이 선행하는 사건에 영향을 받는다고 여겼다. 그리하여 Freud는 정신발달의 단계를 구강기, 항문기, 남근기, 잠재기, 성기기로 시기적으로 구분하여, 아이가 자라면서 각 단계를
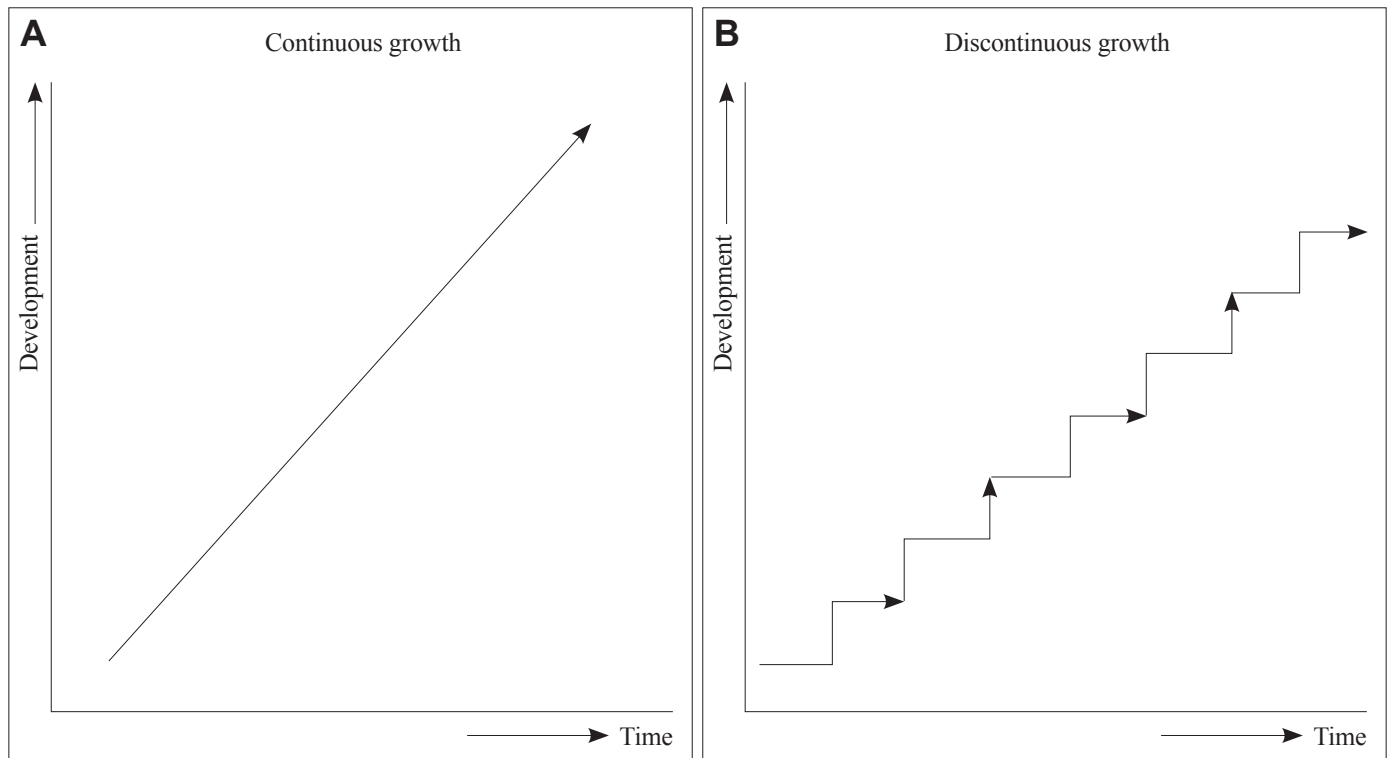

Figure 1. Continuous growth and discontinuous growth.

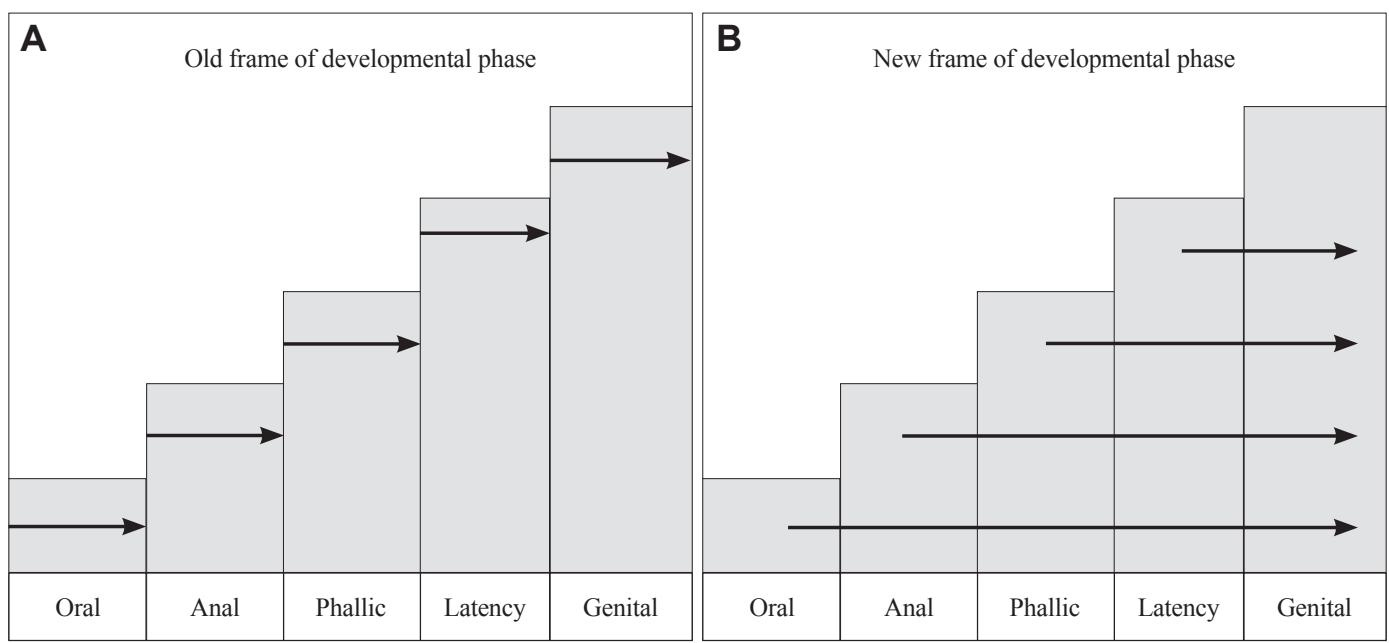

Figure 2. Old frame of phase and new frame of phase in Freud's developmental theory. 
순차적으로 겪으면서 그 시기에 수행해야 하는 과제들을 성 공적으로 습득하지 못하면 더 이상의 발전이 어려우며, 이렇 게 되면 여러 가지 정신병리의 원인이 되고, 더 나아가서는 인격에 영향을 받게 된다고 하였다(Figure 2A). Freud의 이 러한 발달 단계의 이론은 이후 발전하여, 어떤 발달의 과제 가 특정한 시기에 시작하더라도 한 시기에 완성되는 것이 아니라, 일생을 통하여 계속된다는 것으로 바뀌었다. 구강기 에서의 욕구 만족의 여부와 연관된 구순적 성격, 항문기에서 의 강박적 성격, 남근기에서의 나르시시즘 등과 같이 각 발 달 단계에서의 과제들은 각 발달 단계의 시작점에서 출발하 나 일생을 통해 발달함으로써 인간의 정신에 영향을 준다는 것이다(Figure $2 \mathrm{~B}$ ).

Klein은 이러한 발달 단계의 개념을 편집-분열적 입장(paranoid-schizoid position)과 우울 입장(depressed position) 으로 나누어 설명하였다. Klein에 의하면, 생후 1 개월 정도의 발달 초기 단계에서는 편집-분열적 자리(paranoid-schizoid position)가 시작되어 인생에 지속적인 영향을 미치게 된다. 이후 생후 6개월경부터 본인 중심의 편집-분열적 자리(paranoid-schizoid position)에서 다른 사람에 대한 고려를 할 수 있는 우울적 자리(depressed position)로 교체가 일어난다. 따라서 Klein은 인간이 우울적 자리에 도달하는 것을 인간 발달의 중심적 과제이자 성취로 보았다. 그러나 인간이 우울 적 자리(depressed position)로 발달하였다고 해도 여러 가지 원인에 의해 편집-분열적 자리(paranoid-schizoid position) 로 퇴행할 수 있고, 이러한 우울적 자리(depressed position)의 비율이 커졌다고 해서 거기에 머물러 있는 것은 아니다(K1ein 1958). 인간이 발달을 한다는 것은 편집-분열적 자리(paranoid-schizoid position)와 우울적 자리(depressed position) 의 비율이 변화하는 것인데, 다시 말하면 우울적 자리(depressed position)의 비율이 편집-분열적 자리(paranoid-schizoid position)에 비하여 현저히 높아지며 이로 인하여 본인 중심 의 사고보다는 본인과 다른 사람들을 동시에 생각할 수 있는 좀 더 바람직한 상태로 발달한다는 것을 의미한다. Klein의 자리 개념은 이렇게 일생을 통해서 발달해 가는 것이라고 생 각된다(Figure 3).

과거 사춘기 이후에는 자아의 구조적인 변화는 없다고 생각 하였으며, 성인기에 일어나는 변화는 그 전까지 발달한 정신 구조를 가지고 향후 외부 환경에 적응하는 것일 뿐이라는 의견이 팽배하였다. 그러나 그에 반하여 Emde, Colarruso, Nemiroff 등은 사춘기 이후에도 발달은 계속되며, 내적 자 아의 항상성에 영향을 주는 외부 자극이 있는 한, 자아는 스 스로 자제하거나 적응하는 자아구조의 변화를 가져오게 된 다고 하였다(Emde 1985; Colarusso와 Nemiroff 1981). Eri-

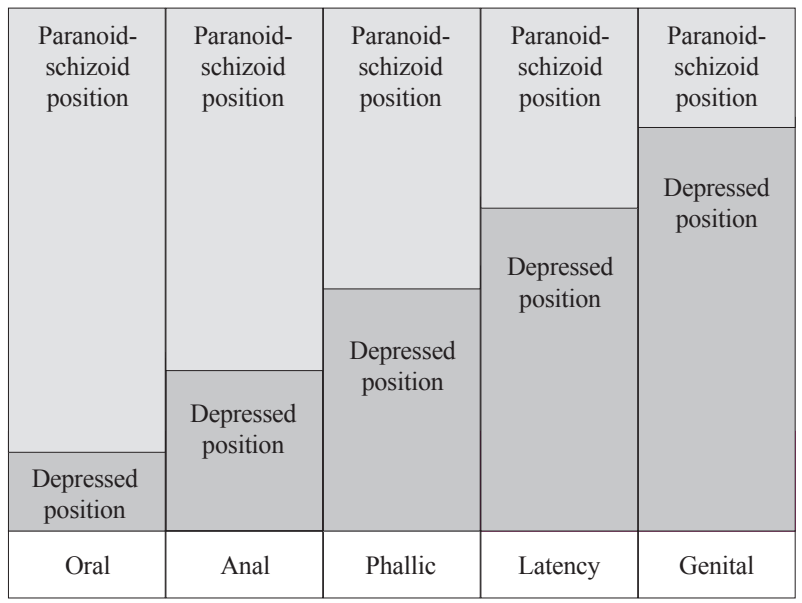

Figure 3. Development in positions.

kson은 초기 발달을 출생 후부터 다른 시기마다 각기 다른 형 태를 지나면서 평생 지속되는 과정으로 보았다(Erikson 1950).

현재까지 여러 발달학자들이 주장하는 이론들 사이에는 몇 가지 유사점과 차이점들이 있다. 다양한 발달이론들이 정 신기구의 발달을 설명하는 공통적인 목적은 인간의 마음이 어떻게 발달하는가에 대한 이유를 찾기 위함이다. 발달이론 을 연구함으로써 임상적으로는 환자의 발달 단계를 파악하 는 의미가 있고, 정신분석적으로 정상과 비정상을 구별할 수 있게 된다는 것도 공통점이라 할 수 있다. 또한 정상적이지 않은 발달은 정신과적 장애의 위험요소가 되고, 특히 인간에 게 발달 초기의 문제가 발생한 경우에 더 심각한 정신병리가 생길 것이라는 사실은 많은 발달이론들이 공유하고 있다. 이 에 반하여 발달이론들마다 강조하는 발달의 근원과 정신분 석 기술(technique)에 영향을 주는 정도는 다르다. 발달이론 의 증거(evidence)가 환자가 자신의 과거를 재구성(reconstruction)하는 것에서 발견되었는지, 소아분석이나 소아를 관찰하여 발견된 것을 채택하였는지, 소아연구를 통해 발견 된 사실을 증거로 삼았는지에 따라 차이가 있다. 발달이론마 다 욕동(drive), 정신구조(structural point of view), 대상관 계(object relation) 중 어떤 것을 강조하느냐에 따라 다른 관 점을 가질 수 있다. 발달개념의 범위에도 발달이론학자마다 의 견해에 차이가 나는데, 예를 들면 Anna Freud, Hartmann, Jacobson 등의 경우 광범위하게 발달이 인생을 거쳐 일어난 다고 생각한 반면, Mahler, Spitz, Hoffer, Kohut 등은 보다 좁고 이른 시기에서 일어나는 성격구조의 발달의 중요성을 강조하였다. 발달 과정에서 발생하는 장애나 손상에 대한 관 점에도 차이점이 있어, 전반적인 발달의 문제가 있어 장애가 발생한다는 이론과, 이와 대조적으로 특정한 시기의 발달이 문제되어 장애가 발생되는 것으로 생각하는 이론이 대두되 었다(Abrams 1983). 


\section{분석이론과 발달이론의 관계}

생애 초기 경험들은 인간이 성장하면서 적응하는 방향을 결정한다. 인간의 신체적 발달의 동력이 유전자에 의한 것이 라면, 정신적 발달의 기본적인 동력은 첫째로 자기 스스로 생 활하는 활력(activity)을 가지고 살기 위함이라 할 수 있다. 이 활력(activity)은 학습이나 강요에 의해 일어난 것이 아니며 인 간이 태어나 초기에 감각운동기관들을 스스로 움직이는 활 동을 통하여 존재한다는 것을 알 수 있다. 두 번째로 기본적 인 발달 동기는 자기제어능력을 배양하기 위함이다. 단기적 관점에서는 수면-각성 주기를 조절하는 것에서부터 장기적 으로는 성장과 필수적인 개발들을 말하는 것이기도 하다. 세 번째는 발달을 통해 타인과의 관계에서 사회생활에 적응하 기 위함이다. 인간은 태어나면서 눈맞춤을 하는 데서부터 타 인과 관계를 맺으면서 살아가는 것에 노출된다. 이후 인사를 하고 다른 이들의 표정이나 언어적 표현들을 배우며 소통하 는 법을 배우게 된다. 네 번째는 자신의 감정 상태를 잘 알기 위해서이다. 부모의 관점에서 보면, 유아는 자신의 감정표현 을 가장 우선적으로 하게 되는데, 유아가 자신의 고통을 중지 하기 위해서 울고, 유쾌한 상호관계를 유지하기 위해 웃게 된 다는 것을 예로 들 수 있다. 마지막으로는 개인의 인지적 통 합을 위함이다. Piaget는 이러한 인지적 통합이 새로운 것을 익숙한 혹은 친숙한 것으로 만들기 위하여 필요하다고 하였 다. 그리고 이런 발달의 동력들은 환자가 분석적 정신치료를 통하여 성취하고자 하는 동기들과 동일하다(Emde 2005).

서론에서 언급하였듯이 초기 정신분석의 목적은 환자의 내면적인 정신세계에서 발현하는 일들에 초점을 두고 통합 하는 능력을 배양하고, 본인의 병식을 얻는 것이었다. 그러나 분석 과정에서 치료자와 환자의 상호관계 자체로 치료 효과가 있고, 환자의 내적인 발달뿐 아니라 상호관계의 발달이 치료 인자로 함께 공존한다는 사실을 알게 되었다. 그리하여 개인 의 내면세계에 대한 연구가 상호관계의 연구로, 한 사람의 심 리학(one person psychology)이 적어도 두 사람의 심리학 (two person psychology)으로 패러다임이 변화됨에 따라, 정신분석 과정 중에 환자가 과거에서부터 현재까지의 경험 을 통합하는 것뿐만 아니라 치료자와의 상호관계가 진전되 면서 전반적인 대인관계의 양질이 발전하는 것이 중요하게 되었다. 즉 정신분석적 과정에는 내면적 정신(intrapsychic) 의 발달뿐 아니라 상호 대인관계(interpersonal relationship) 에서의 발달이 공존하게 된다(Abrams 1990).

Freud는 치료자와의 전이현상이 극대화됨에 따라 전이신 경증(transference neurosis)이 발생하여 일상의 모든 활동들 이 치료자와 연관 지어지면서 환자가 기존에 가지고 있던 신 경증적인 증상이 사라진다고 설명하였다. 그리고 분석 과정을
통하여 전이신경증이 해소됨으로써 기존에 문제가 되었던 신경증이 치료된다고 설명하였다(Freud 1916 1917). Meissner(1982)는 그에 비해 환자와 치료자 관계의 중요성에 대해 강조하였고, 이런 전이신경증의 해소는 치료자와의 적극적 인 관계형성으로 인해 일어나는 내재화(internalization)를 통해 일어난다고 보았다. 즉 환자와 치료자의 공동작업의 결 과로, 환자의 내면적 정신 과정(intrapsychic process)뿐만 아 니라 치료자에 대한 어떤 환상(fantasy), 꿈, 공상, 기억 등이 만들어지게 된다는 것이다. Meissner는 이러한 치료자에 대 한 환상, 꿈, 공상, 기억 등이 만들어지는 과정은 치료자의 실제적 특성이 환자의 정신적 발달을 일어나게 한다는 사실 을 보여 주는 것이라고 하였다. 이것은 치료자가 발달을 가 져오는 대상(development object)으로서의 역할을 한다는 개념이기도 하다.

정신분석 및 분석적 정신치료 과정 중에서 치료자는 전이 현상을 통하여 환자의 중심이었던 과거의 한 인물의 역할을 하게 되면서, 환자는 치료자라는 새로운 대상과 관계를 가지 는 동시에 과거의 한 인물을 향해 느꼈던 감정을 되살리게 된다. 그리하여 환자가 분석 과정 동안 치료자와의 개별-분 리화 과정이 일어나면서, 면담실 안에서 치료자와 환자 사이 에서 벌어지는 '지금-여기(here and now)'의 일들이 실제로 는 자신이 경험하였던 과거 인물의 이미지를 투사해서 반복 적으로 일어나던 일들이라는 사실을 깨닫게 된다. 이로 인하 여 환자는 자신의 증상을 직면할 수 있게 되고, 내적인 힘이 강화된 자아가 발달함에 따라, 증상이 점차적으로 호전된다. 즉 환자는 전이현상을 통해서 자신의 내부 모습을 이해할 수 있을 뿐만 아니라, 환자-치료자 사이의 관계가 어떤 형태를 취하는지, 즉 상호관계의 모습도 이해할 수 있다는 것이다 (Abrams 1996).

\section{소아 및 낮은 수준의 인격장애 환자들에게 더욱 중요한 환자- 치료자 관계}

앞서 언급하였듯이 정신분석의 방법에 고전적인 해석방 법 이외에 다른 치료요소(상호관계)가 있을 수 있다는 관점 이 생기면서, 상호관계의 발달이 일어나는 정신적 발달이론 에 대한 관심이 증가하였다. 따라서 발달이론의 개념이 최근 의 정신분석치료 환경에서 더욱 중요하게 되는 이유에 대해 서 살펴볼 필요가 있다고 생각한다.

소아분석의 경우 소아는 성인에 비하여 자신의 감정과 생 각을 자유롭게 표현하는 언어적 능력과 자유연상의 능력에 한계가 있으므로, 환자에게 해석을 해주는 대신 발달상에서 문제가 있다고 생각하는 단계가 발전할 수 있도록 하는 것이 적합한 일이라 하겠다(Abrams 1990). 정신분석 및 분석적 정 
신치료에서 치료자가 환자의 방어기제를 해석하는 것은 오 히려 정신적 발달을 저해하는 장애요소가 될 수도 있다(Tyson과 Tyson 1990).

Hug-Hellmuth는 소아정신분석치료에 대하여 소아들은 자유연상을 언어로 표현하기에는 성숙되지 않아 정신분석적 으로 무의식적 환상이나 소망을 해석할 정도의 의미 있는 전 이가 발생하지 않는다고 하였다(Shin 1998). 또한 소아는 부 모에 대한 애착이 강하기 때문에 치료자에 대한 애착이 부 모에 비해 현저하게 적어 전이현상이 잘 일어나지 않기 때 문에, 소아에게 있어 정신분석이 유의미한가에 대한 논란이 있었다. Klein(1932)과 Freud(1965)는 소아에게 놀이를 이용 한 정신분석치료를 고안하였고, 무의식을 언어로 표현하는 대신에 놀이를 통하여 소아가 자신의 감정을 자유롭게 표현 할 수 있도록 하였다. 이때 아동이 느끼는 내적 갈등이 놀이 를 통하여 보다 명확하게 이해되고, 그러한 갈등을 극복하고 표현하도록 아동을 유도하며 갈등의 의미를 해석하는 작업 이 전통적인 의미의 정신분석적 놀이 치료의 형태라고 할 수 있다. 그러나 최근에는 많은 소아정신분석가나 치료자들이 놀이 자체가 가지고 있는 치료적인 역할에 관심을 갖고 놀이 를 수행하는 과정이 바로 치료적이며, 회복기능을 갖고 있다 고 생각한다(Shin 2008). 임상적인 면으로는 성인과 마찬가 지로 소아가 정신분석을 받으면서 자신의 증상에 대한 의미 (병식)를 잘 알지 못하더라도, 증상의 호전이 일어나는 경험 을 할 수 있다. 즉, 소아의 정신분석의 핵심적인 치료요인은 이 제껏 정신분석에서 치료요인으로 생각하는 고전적인 해석 대신 치료자와의 상호관계(interaction)를 통한 소아의 발달 자체라고도 볼 수 있다.

이처럼 소아의 정신분석에서 일어난 발달의 개념을 낮은 수준(lower level)의 인격장애 환자들(예: 중독, 식이장애 환 자, 자기애성 인격 환자, 경계성 인격장애 환자, 편집증적 환 자, 학대의 경험이 있는 경우)에게 대입해 보면, 이들의 분석 치료 과정에서도 환자-치료자의 상호관계가 낮은 수준의 인격장애 환자들의 정신적 발달에 중요한 역할을 한다는 것 을 짐작할 수 있다.

그러므로 저자들은 현대 정신분석에서 전통적인 해석방법 이 치료의 핵심이라는 정신분석의 관점을 보완하여, 분석 과 정 중에서 환자의 발달이 진행되는 것이 점점 중요하게 여겨 지는 추세라고 생각한다. 환자는 분석 과정에서 과거의 경험 에서 일어났던 감정을 전이를 통해 치료자에게 느끼게 되고, 재구성하게 되면서 자신에 대한 병식을 가지게 되므로, 역동 적인 구조 안에서 환자가 자신의 내면세계를 탐구할 뿐 아 니라, 환자-치료자의 상호관계를 통하여 본인의 마음에 대 한 이해를 넓혀간다. 이는 인간의 발달 과정을 소아의 정신분
석, 분석적 정신치료와 성인의 정신분석 및 분석적 정신치료 에서도 사용할 수 있다는 점에서 매우 유용하다.

\section{정신분석의 치료요인으로서의 환자-치료자 상호관계}

치료자는 인간의 발달 과정 중에서도 특히 생에 초기에 일 어나는 영유아와 주양육자 사이의 대인관계 발달 과정이 정 신분석 및 분석적 정신치료에서 일어나는 환자와 치료자 사 이의 상호작용에서도 유사하게 일어난다는 사실을 염두에 두어야 한다(Emde 2005). 그러므로 치료자는 다음과 같은 초 기 모자관계와 환자-치료자 관계의 공통점들을 잘 인식하는 것이 필요하다고 저자들은 생각하는 바이다.

첫째, 발달 과정에서 유아는 언제나 어머니와 함께 있는 것을 원하는 것처럼 환자는 치료자와 함께 있기를 원한다는 사실이다. 이때 어머니가 아이와의 관계에서 적극적이고 적절 하게 참여해야 아이의 발달이 잘 일어나는 것처럼, 치료자가 적극적으로 분석 과정에 참여하지 않으면 환자의 정신발달 과정은 일어나지 않을 가능성이 높다. 이때 치료자는 환자의 수준에 맞추어 정신치료를 진행하여야 하는데, 이는 전이경 험의 중심적인 역할과 그 맥락을 같이 하게 된다. 결론적으로 아이와 어머니를 분리해서 생각할 수 없듯이 환자와 치료자 의 상호관계를 보지 않고서는 환자를 이해할 수 없다.

두 번째, 발달 초기에서는 아이가 원할 때 언제든지 곁에 어머니가 있어야 하는 것처럼 환자 역시 정신치료 초기에는 환자가 원하는 시점에 치료자를 만남으로써 기초적인 신뢰 감과 기대에 대한 항상성이 생긴다는 점이다. 이는 치료적 동 맹을 형성하는 데 필수적인 요소이며, 일정한 제한과 규칙을 통하여 이루어질 수 있다. 치료자는 환자에게 제한과 규칙 (regulation)을 가지게 하는 동시에 균형(balance)을 유지하여 야 한다. 가령 치료자는 환자가 본인의 감정을 충분히 느낄 수 있도록 하는 감정의 명료화(clarification)가 환자에게 인 지(cognition)를 제공하는 해석을 해주는 데 있어서 균형을 유지해야 함을 의미한다. 그러므로, 아이가 원할 때에는 언 제나 어머니가 있어 주는 것이 바람직한 것과 같이 환자가 도 움을 원할 때 치료자가 적절히 도움을 줄 수 있는 위치에 있 다면(be available), 이는 치료적으로도 매우 유용한 일이다. 예를 들어, 정신치료를 종결한 환자가 다른 문제로 5년 후 같은 치료자를 찾아간다고 가정할 때, 그 치료자가 환자에게 도움을 줄 수 있는 위치에 있다는 것(be available)이 치료적 으로 중요하다는 것이다.

세 번째, 초기 발달 과정에서 일어나는 모자 사이의 감정과 관계되는 반응은 치료 과정에서도 동일하게 일어난다는 것 이다. 즉 생에 발달 초기에서 어머니가 아이의 감정 상태에 예민하게 관심을 기울여 아이를 달래면서 안정감을 주는 행 
위는, 실제적으로는 어머니 본인이 가지고 있는 감정들을 이 해하고 이용하여 아이의 감정 상태를 짐작할 수 있어야 행해 질 수 있다. 이처럼 정신분석 및 분석적 정신치료 과정에서 도 치료자는 환자가 치료자에게 느끼게 하는 감정을 스스로 느낌으로써 환자가 가지고 있는 감정을 이해하게 되는데, 이 것은 Freud가 치료자의 역할을 환자에게 치료자의 모습을 철저히 감춘 채 환자의 모습만 거울에 비추어 주듯이 행한 기법과는 다른 것이다. 이것은 어머니가 아이의 능력을 파악 하고 감정을 이해하여 달래는 행위처럼, 치료자가 환자의 능 력을 파악하고 환자에게 환자가 견딜 수 있을 정도의 감정 을 되돌려 줌으로써, 궁극적으로는 환자로 하여금 자신에게 극단적이고 부정적인 감정조차도 잘 조절하고 참아낼 수 있 게 하는 것이다. 이것은 아이가 자기가 감당할 수 없는 감정 을 느낄 때 어머니에게 이것이 무엇인지 가르쳐 달라는 뜻에 서 자기가 감당할 수 없는 감정을 투사한다는 투사적 동일 시(projective identification)의 이론과 잘 맞아떨어진다.

네 번째, 어머니와 치료자가 모두 공감적인 태도를 취해야 한다는 것에서 정신분석 및 정신치료의 환경 자체는 Winnicott가 주장한 안아 주는 환경(holding environment)과 비 슷함을 염두에 두어야 한다. 단, 치료자가 환자에게 안아 주는 환경을 제공한다는 것이, 치료자가 선량한 치료자(benevolent object)로서 환자에게 부족한 부분을 메꾸어 주는 역할 을 하는 것이 아니라 환자를 충분히 이해하고 이를 환자에 게 돌려주는 역할을 하는 것이다. 환자에게 공감을 해주는 능력은 환자에게 무의식을 해석해 주는 능력만큼 중요하다. Kohut는 이러한 공감능력에 실패한 어머니의 경우가 정신 적 병리의 원인이 되며, 치료자에 의해 수정된 공감적 경험 (corrected empathic experience)을 환자가 하게 될 때 멈추 어져 있던 발달이 다시 재개된다고 하였다(Kohut 1971). 공 감은 분석치료에 있어서 치료자의 목표가 되는 것이 아니라 치료 과정이 잘 일어나게 하는 하나의 수단으로서의 역할을 한다. 치료자는 환자의 주관적인 감정이 무엇인지 느끼려고 노력하는 동시에 객관적으로 치료 과정을 바라보는 시선을 가져야 한다. 치료자는 자신에게 남아 있는 나르시시즘을 줄 이고 구조화된 수용성을 유지함으로써 환자를 공감적으로 이해할 수 있다. Goldberg는 환자가 분석가의 공감적 태도 에 의하여 스스로에 대한 이해가 이루어지면 정신구조적인 변화가 가능하다고 하였다(Goldberg 1988). 정신분석 및 분 석적 정신치료 과정 중에서 환자는 치료자가 공감하는 감정 으로 인해 스스로 느끼는 부정적이고 고통스러운 감정에도 불구하고 자신의 의식과 무의식을 탐구하는 것을 계속하게 되는데, 이때 치료자는 환자가 예상하지 못한 감정을 참아 내는 능력을 점차적으로 독려하는 역할을 한다. 이 과정에서
치료자가 공감적인 태도를 유지한다는 것은 치료자가 환자 에게 전이경험에서의 왜곡을 지적하는 대신 그 왜곡의 원인 을 환자와 함께 연구하는 자세를 유지하는 것으로 볼 수 있 다. 따라서 궁극적으로는 환자로 하여금 본인 과거의 자신에 대한 공감을 느끼게 하는 것이 치료 목표가 된다.

마지막으로 어머니 혹은 치료자가 아이나 환자의 행동, 감 정, 생각을 해석할 때 발달론적으로 적합한 단계에 맞게 해석 을 하여야 한다는 것이다. 즉 어머니가 아이를 키우듯이, 해 석은 환자의 발달 단계와 개인 역량에 맞아야 한다. 이는 치 료자가 환자의 경험을 상상할 수 있는 만큼의 범주에서 가능 하기 때문에 환자를 충분히 이해하는(마치 자신의 상태처럼 환자를 이해하는) 대리적 내성(vicarious introspection)이 필 요하므로, 치료자에게는 인지적인 능력과 객관적으로 환자 의 상황을 평가할 수 있는 능력, 그리고 다른 사람의 입장과 환경에 대한 지식적인 부분이 필요하다.

\section{결 론}

본 논문은 다음 다섯 가지를 강조하였다. 즉 첫째, 인간의 발달은 육체적인 것뿐만 아니고 정신적인 발달을 포함한다 는 것을 아는 것이 중요하다. 둘째, 정신적인 발달을 함에 있 어서 개인 독자적으로 발달을 이룩하는 면도 있겠지만, 이러 한 정신적인 발달을 위해서는 개인과 그 개인을 돌보는 사 람과의 상호작용, 특히 생에 초기의 모자관계의 상호작용이 개인의 발달을 가져오는 데 있어서 중요한 역할을 한다는 것 이다. 셋째, 정신분석 및 분석적 정신치료에서 이루어지는 환 자-치료자의 상호관계의 발달은 인간의 생에 초기의 모자 의 상호관계의 발달과 비슷하며, 이것이 정신분석 및 정신치 료의 치료요인으로 중요하다는 것이다. 그러므로 넷째, 정신 분석 및 분석적 정신치료에서 환자-치료자 간의 상호관계 의 발달을 가져오는 방법을 연구하는 것이 치료자의 해석을 통한 환자의 병식 못지 않게 중요하게 생각되고 다루어져야 한다는 것이다. 또한 다섯째, 인간의 정신적 발달 과정은 정신 분석 과정을 통해서도 동일하게 일어나는데, 정신적 발달 과 정이 일생을 두고 계속적으로 일어나는 것처럼 정신분석이 나 분석적 정신치료를 통한 과정에서 일어나는 정신적 발달 과정이 정신분석이나 정신치료가 끝난 후에도 지속적으로 일어난다는 것이다.

인간의 정신적인 발달을 자아의 발달로 보면 사춘기에 끝 이 나고 그 이후에는 이전에 발달된 자아를 가지고 살아간 다는 점에서 적응이라고도 할 수 있다. 그러나 최근에는 인간 의 평형상태(equilibrium state)를 깨는 자극 및 사건이 존재 하는 한 인간의 정신적인 발달이 계속된다는 것으로 정신적 
인 발달 개념의 확장이 이루어지고 있다. 또한 최근에는 정 신분석에서 성인기의 발달, 중년기 및 노년기의 발달도 의미 가 있는 것으로 생각되는 추세인데 이것은 발달이란 것이 이전의 시기에는 생각해 보지 못했던 새로운 시각으로 생각 해 본다는 변형(transformation)의 개념이 들어 있다는 사실 과 그 맥락을 같이 한다고 보겠다. 이러한 추세와 더불어 최 근에 등장하는 발달이론은 발달이론이 설명하는 발달의 범 위가 개인의 성숙과 성장에 관한 관점뿐 아니라 개인이 맺 는 타인과의 대인관계의 발달까지 포함하게 되었다. 본 논문 에서는 이런 대인관계 발달에서 초발점이라고 볼 수 있는 초기 모자관계의 중요성을 강조하며 초기 모자관계와 환자치료자 관계 사이에서 일어나는 유사점에 대해 살펴보았는 데, 이는 정신분석 및 분석적 정신치료 과정에서 초기 애착관 계와 같은 환자-치료자 간의 상호관계가 중요한 치료인자 가 될 수 있다는 점을 암시한다.

환자-치료자 간의 상호관계가 치료인자가 되는 것은 첫째, 과거에 환자가 어머니와 경험하지 못한 안아 주는 환경(holding environment)을 치료자와의 관계에서 경험함으로써 환자의 정지되어 있던 발달 단계가 계속적으로 일어나기 때 문이고, 둘째, 정상적인 발달을 초래하는 치료자의 역할이 있 기 때문이다. 또한 모자관계 자체가 시간이 지나면서 점점 발 달해 가는 것처럼, 환자-치료자 간의 상호관계도 환자와 치 료자가 적극적으로 정신분석적 과정에 참여함에 따라 그들 의 상호작용도 점점 발달해 간다는 사실을 이야기하고자 하 였다.

본 논문은 자아심리학(ego psychology)의 정신분석의 요체 에 대한 설명, 즉 환자의 자유연상을 통한 무의식의 출현과 이러한 무의식의 의미를 치료자가 해석하여 환자에게 병식 을 만들어 주는 것뿐만 아니라, 대상관계이론(object relations theory)의 정신분석의 요체에 대한 설명, 즉 환자-치료자 간 의 상호작용이 환자의 정신적인 발달을 가져오기도 한다는 것을 이야기하며, 이러한 상호작용이 정신분석 및 분석적 정 신치료에서 궁극적으로는 환자의 치료에 중요한 요소가 된 다는 것을 이야기하였다. 여기에서 가장 중요한 핵심은 초기 모자관계이며, 이 부분은 공통적으로 발달이론들에서 강조
되어 왔고, 현대 정신분석에서 더욱 관심을 두고 있는 것으 로 판명되었다. 그러므로 앞으로 정신분석과 분석적 정신치 료에서 치료인자로서의 상호작용의 중요성을 인식하고, 환 자를 평가하는 데 있어서 출생 후 3세까지의 초기 모자관계 에 대한 평가와 모색에 더 많은 노력이 필요하며, 앞으로 발 달이론에 대한 연구도 마찬가지로 이러한 영역에 집중하는 것이 필요하다고 생각하는 바이다.

\section{Conflicts of Interest}

The authors have no financial conflicts of interest.

\section{REFERENCES}

Abrams S. Development. Psychoanal Study Child 1983;38:113-139.

Abrams S. Differentiation and integration. Psychoanal Study Child 1996; 51:25-34.

Abrams S. The psychoanalytic process: the developmental and the integrative. Psychoanal Q 1990;59:650-677.

Choi EK, Ha JH. Challenge for the entry of psychoanalytic concepts in personality disorders in DSM-5. Psychoanalysis 2013;24:102-110.

Colarusso CA, Nemiroff RA. Ault development: a new dimension in psychodynamic theory and practice. New York: Plenum Press;1981.

Emde RN. A developmental orientation for contemporary psychoanalysis. In: Gabbard G, Person E, Cooper A. Textbook of psychoanalysis. Washington: American Psychiatric Publishing;2005. p.117-130.

Emde RN. From adolescence to midlife: remodeling the structure of adult development. J Am Psychoanal Assoc 1985;33:59-112.

Erikson EH. Childhood and society. New York: Norton;1950.

Freud A. Normality and pathology in childhood: assessments of development. New York: International Universities Press; 1965.

Freud S. Introductory lectures on psychoanalysis (1916-1917). The standard edition of the complete psychological works of Sigmund Freud, Vol 15. Translated by Strachey J. London: Hogarth Press;1963.

Goldberg A. Changing psychic structure through treatment: from empathy to self reflection. J Am Psychoanal Assoc 1988;36:211-224.

Klein M. On the development of mental functioning. Int J Psychoanal 1958;39:84-90

Klein M. The psychoanalysis of children. London: Hogarth Press;1932.

Kohut H. The analysis of the self: a systematic approach to the psychoanalytic treatment of narcissistic personality disorders. New York: International Universities Press;1971.

Meissner WW. Approaches in psychotherapy (a conference): discussion. Contemp Psychoanal 1982;18:487-497.

Shin SH. A review of the development of child psychoanalysis. Psychoanalysis 1998;9:305-318.

Shin SH. Playing and reality by Donald W. Winnicott. J Korean Psychoanal Soc 2008;19:14-19.

Tyson P, Tyson RL. Psychoanalytic theories of development: an Integration. New Haven, CT: Yale University Press; 1990. 